\title{
Curriculum and Youth and Adult Education: Power/Knowledge Space
}

\author{
O currículo e a educação de jovens e adultos: espaço \\ de poder-saber
}

Elizabeth Gottschalg RAIMANN

\begin{abstract}
Curriculum establishes which knowledge is prioritized, such as that regarding views on the world and humanity and which "truth" to proclaim. Curricular theory gives epistemological support to what the curriculum will do through the curricular policies that will make viable the curriculum proposal, through holdings and documents at the macro and micro level. In class the curriculum fulfills certain roles and relationships between teacher and students and validates some knowledge while invalidating others, including certain individuals and excluding others. We understand curriculum as a trajectory that involves the entire dynamic in and for the school, in order to produce identities and subjectivities. The objective of this study is to problematize the curriculum field, focusing specifically on the education of youth and adults from a post-critical viewpoint. From this perspective, Youth and Adult Education begins to be perceived as a form of education in terms of the cultural political field: a space of power/knowledge that produces different identities.
\end{abstract}

Index Terms: Youth and Adult Education, Curriculum, Power/Knowledge.

\section{RESUMO}

O currículo estabelece quais conhecimentos priorizar em relação a outros, bem como qual a visão de mundo e de homem, e qual "verdade" proclamar. A teoria curricular dá sustentação epistemológica ao que o currículo irá efetivar através das políticas curriculares que, por sua vez, viabilizarão a proposta do currículo, por meio de ações e de documentos em nível macro e micro. Em sala de aula o currículo opera determinando papéis, relações entre professor e alunos, validam certos conhecimentos e outros não, incluem certos indivíduos, excluindo outros. Entendemos o currículo como uma trajetória que envolve toda a dinâmica na e para a escola, com fins a produzir identidades e subjetividades. Neste estudo, como objetivo, procuramos problematizar o campo do currículo, enfocando especificamente a educação de jovens e adultos numa visão pós-critica 
apontando algumas implicações para a mesma. Nesta perspectiva, a Educação de Jovens e Adultos passa a ser percebida como uma educação em termos de campo político cultural; um espaço de saber-poder que produz diferentes identidades.

Palavras-chave: Educação de Jovens e Adultos, Currículo, Poder-Saber.

\section{Introduction}

Curriculum establishes which knowledge is prioritized, such as that regarding views on the world and humanity and which "truth" to proclaim. Curricular theory gives epistemological support to the effectuation of curriculum in basic education through the curricular policies that will make viable the curriculum proposal, through holdings and documents at the macro and micro level.

In discussions about educational practices, in proposing reforms and restructuring, curricular matters become central. These reforms propitiate a battleground between various dominant groups. Through discussions and pressure, these groups seek to implement their ideas around the various meanings of social and political matters. In this way, historically, these dominant ideas - a Eurocentric vision of the white man, of the Christian religion, of the capitalist world - permeate educational perspectives on school curriculum.

Curricular policies at the macro level authorize certain groups of specialists to the detriment of others, which is an example of what Silva affirms: they "fabricate the epistemological objects that they speak about, through their own lexicon...this is a highly efficient mechanism of the institution and constitution of reality" (1999, p.11). In addition, they attribute specific holdings and documents and generate directives, curricular guidelines, norms, grades and textbooks. At the micro level (already in the form of curriculum) in the classroom, they fulfill specific roles and relationships between the teacher and the students, validating certain 
knowledge over other knowledge, and including certain individuals while excluding others (SILVA, 1999).

From this perspective, when we discuss curriculum as a trajectory that involves all of the dynamics in and for school, with the objective of producing identities and subjectivities, it becomes necessary to determine from what theoretical position this discussion is occurring, remembering that implicitly in such a position certain visions of the world and humankind are overlapping.

This work attempts to problematize certain questions regarding the curricular field, focusing specifically on youth and adult education with a post-critical vision considering the contributions of Foucault. It presents the results of the study conducted with a class of adults ${ }^{1}$ in the city of Itumbiara in the state of Goiás, regarding the use of the textbook or didactic book. Lastly, this work reflects on some possibilities for this modality of instruction stemming from post-critical theories as a reference point.

\section{Curriculum from a post-critical view:}

If we consider the changes that have occurred in the $20^{\text {th }}$ century in the various sectors of the social, political, economic and scientific spheres, all of which propose a new social order, one cannot forget to consider the possibility that we are going through a paradigmatic crisis.

Veríssimo (1997a) affirms that the changes include basic elements to offer to post-modernity. Just as political power and culture are redefined by globalization, as is the dislocation of power in a decentralized way without defined territory. The changes in nature due to the forces of production and the new social movements are defined in a critical and decisive way.

\footnotetext{
${ }^{1}$ Youth and Adult Education in Brazil is divided into segments and the group of adults studied for this paper were students of Segment One, which covers elementary education.
} 
Education, in light of this context, is not immune to the influences that circulate in current discussions and practices. The educational sphere reflects and legitimizes the project of society that is proposed in different historical moments.

Just as in medieval times an ontological model formed the basis of education, modernism is based on a model grounded in Enlightenment reason, which prioritizes scientific and technical reason. What, then, does post-modernism offer us?

Post-modernist thought does not believe in a singular project for society, for it perceives reality in a complex way. Such thinking allows for possibilities heretofore unknown, generating insecurities, since we are not accustomed to handling uncertainties, particularly in education.

In this context, education finds itself facing a challenge. It becomes necessary to conduct an analysis of both the liberal and the criticalprogressive theoretical-methodological proposals. Both, with a vision of binary relationships of good and evil, oppressed and liberated, naïve and wise, which in their educational projects reveal their understanding of education as a work of awareness, leading the individual to enlightenment, liberation and autonomy (VERÍSSIMO, 1997a).

Post-modern discourse attempts to offer a different focus to educational theory, no longer taking into account the totalizing discourse, but rather the discourse that considers plurality. It also considers the differences in subjectivities and the various narratives that allow for other takes on reality. What then, would be the curricular proposal from this perspective?

According to Silva (2001), there does not exist a curricular theory but rather attitudes influenced by post-modern concepts about curriculum.

From this point of view, one characteristic of the curriculum would be to observe "the process of signification as fundamentally indeterminable and unstable...as it is not pre-existing, it is culturally and socially produced" 
(SILVA, 2001, p.123). In this way, knowledge goes on to be examined in the sense of the options made, considering why this knowledge and not that knowledge, who does this knowledge benefit and why. Other attitudes, present in this line of thought, would be the questioning done regarding the notion of truth and the conception of the subject. In regards to the former, what is presented is not knowing what is true but why it became true. It is interested in the transcendental meanings related to religion, patriotism, politics and the sciences present in the curriculum and by the binary relationships present such as masculine/feminine, white/black, scientific/non-scientific, heterosexual/homosexual, seeking its deconstruction. In regards to the subject, the humanist concept of subject and conscious subject of emancipatory education is problematized. From a post-modern perspective, identity is produced from the discourses and devices present in society. Silva (2001) argues that the post-critical perspective should combine with critical theory, contributing to a more ample understanding of curriculum, which is that of curriculum as a matter of knowledge, identity and power.

From a post-critical perspective, youth and adult education will suffer a considerable change. Instead of seeking an education for awareness, we will come to view education in terms of a cultural political field.

We have observed until now that the different proposals for youth and adult education, developed by various segments both governmental and non-governmental, have based themselves on the theoretical-methodological approach of Paulo Freire. In his educational practices, both in literacy and in further study, these same segments, through an emancipatory project of society, have searched for pedagogical practices that have as their objective to make students aware and to fight for their rights as citizens, taking advantage of their insertion into present-day society (SOARES, 2001; ANPED, 2002). 
Post-critical thought, a reference point for social movements and multicultural and gender studies (SILVA, 2001; COSTA, 1998) comes to perceive education, pedagogy and curriculum as a cultural theory, battlegrounds and symbolic conflicts, questioning contents and the nature of the knowledge propagated (VERÍSSIMO, 1997b).

In the next segment, the current curriculum for youth and adult education is problematized as the result of a study conducted with a youth and adult education class.

\section{The classroom: a battleground of power-knowledge}

With a focus on youth and adult education, specifically a municipal school in the city of Itumbiara in the state of Goiás, which offers the first segment of youth and adult education - first through fourth grades - we analyzed the complexity of the relationships of power/knowledge that through practices and discourses, produce students of this modality of instruction, individualizing them and subjecting them to themselves and capitalist society.

As to the procedures of this study, we used the non-structured interview with the head teacher and observation of the classroom, analyzing some pedagogical practices developed such as the choosing and use of didactic books (LAVILLE; DIONNE, 1999).

From a Foucauldian perspective, the classroom is a laboratory of power that makes possible that production of discourses and practices for the field of pedagogy. The produced discourses, through the power/knowledge relationship, attempt to establish themselves as regimes of truth and are elaborated through disciplinary devices present in the observation, the confession, the subjects, the use of academic space and time. Through pedagogical practices - developed by teachers in the classroom - such as "repeat the aforementioned through historical 
narratives, exposition of legitimated, authorized and reproduced understandings through the quotidian ritual of expositive classes, studies, exams [and] evaluations" (CARLOS, 2002, p.110), what will occur is the production of pedagogical discourses for the individualization of the individuals and no less important, their subjection.

Foucault argues that "the individual is without doubt the fictitious atom of an ideological representation of society, but is also a reality fabricated by this specific technology of power that is called discipline" (2001 b, p.161). In this way, the individual becomes an artifact fabricated by the discursive practices in which the field of pedagogy is located and in this sense, power becomes productive, since through its devices, it attempts to raise a full understanding in regards to this individual to establish "truths" and to contribute to bringing forward a project of humanity and society, or in other words, the objectives of education.

The school of neoliberal capitalist society is produced by this society, which redefines its education in terms of the market, at the same time that this education fabricates a type of individual to serve this same society.

In addressing power and the formation of a disciplinary society, Foucault mentions the architecture of the Panopticon, whose founding is based on a disciplinary device of the "eye" that induces constant vigilance.

Apart from this architectural structure, Foucault proposes another understanding of the Panopticon. This would be "like a machine to conduct experiments, modify behavior, train and retrain individuals...attempt pedagogical experiments" (FOUCAULT, 2001 b, p. 168). This device of observation would be something similar to a laboratory of power in the production of knowledge. Thus knowledge, in turn, refueled by power, would drive towards the power-knowledge relationship that produces discourses and subjects.

Looking at this perception it is possible to say that inside of the municipal school studied, similar and subtler control mechanisms also exist. 
The classroom, just like the school, is also subject to disciplinary devices such as the (teacher's) look, tests and classification. The difference lies in that, despite these devices, there is a technology of me, or in other words, control over oneself makes it so this device becomes more incisive on the body, leading each student to self-regulate, self-discipline. This selfdiscipline is verified during group work, in the division of didactic materials, in sitting in a circle, listening and waiting for their turn to speak.

In general, pedagogical practices carried out in the classroom are established in a battleground and pedagogical practices that in themselves are liberating or repressive do not exist. As the relationships of power circulate, rather than stay in one place, any practice can become an exercise of power and any practice is capable of becoming a source of resistance.

In the observation and analysis of the practices developed by the teacher and the use of didactic-pedagogical material it is possible to observe a distancing from the reality of the students in youth and adult education.

The head teacher of the class recounted that she used some didactic books and argued that it was necessary to use several of them, since there “didn't exist a didactic book that specifically addressed a youth and adult class, so I took content from here and there to address [the students'] needs."

The books presented were the books from the collection "Live and Learn" of Portuguese 1, Mathematics and the Sciences, from Modern Publisher and the student textbook "Live, Learn" 1, Modules 1 and 2 of Educational Action. From these, we analyzed Portuguese 1 and Book 1 of "Live, Learn" and attempted to identify devices that would produce truths about reality and the academic subjects. Despite the similarity in the titles, the books are directed at two distinct audiences. The first collection is made for first-grade children and the second for youth and adults. 
In the Portuguese 1 book, the texts infantilize the content, leading the EJA $^{2}$ student towards uncritical learning, which does not correspond with the proposal of justification for the National Standard Curriculum (that set by the National Ministry of Education). What is of note is the selective and de-contextualized form in which the text, grammar and the very drawings in the book are treated. The book uses stereotypical drawings of animals as well as people, the majority of whom are not part of the students' quotidian reality. Study of the text, in addition to not favoring critical thinking, attempts to extract from the child - to whom the book is directed - a truth about herself, making her speak of her habits and tastes.

We now turn to Book 1, Modules 1 and 2 of the "Live, Learn" collection. Vóvio (2001) explains that the themes addressed in Book 1 have as their thematic axis the identity of the students, or in other words, they identify the people, their stories and their way of life, the space in which they live, their body.

Book 1 of this module proposes to work with student identity. On the first page two questions are presented: Who am I? Who are we?

The unit in question goes on to work with exercises that are common in literacy for all ages and not just for youth and adults. In other words, these exercises aim to elevate the identity of the student, to speak of herself and recognize her own name, identifying herself within the set of the letters of the alphabet. The questions raised on this page and those following aim to guide the student of youth and adult education to tell her story. The intention is not only to give the student a voice, but to also ensure that the student recognizes herself while speaking, subjectifying and subjecting herself simultaneously in her speech.

\footnotetext{
${ }^{2}$ EJA is an acronym for youth and adult education in Portuguese (Educação de Jovens e Adultos).
} 
Here it is possible to perceive what Larrosa (2002), Deacon and Parker (2002) observe in regards to the experience of self. It is inferred that the student, in presenting herself to the teacher and her classmates is exposing herself in speaking of herself, perhaps what she might like to be or what they would like her to be. In this case, the student's speech subjects the student, according to what Foucault thought in regards to the subject.

The contents present in these two units of the books and the exercises proposed remit the justification of the National Standard Curriculum for EJA; it is a document that offers a series of actions that should be mobilized by the teacher and emphasizes the necessity of the educator to take into account the student's reality, value her experience, aside from proposing content that is "significant, scientifically constructed, functional, takes into consideration the students' skills and their cognitive and affective possibilities" (GOIÁS, Currículo Pleno, 2001).

Although this document provides evidence for the importance of contextualization of content and valuing student experience, it does not argue with the constitution of academic knowledge of content itself, not here nor in other instances involving higher government bodies, such as the Ministry of Education's Secretary of Basic Education. In this sense, academic content is considered legitimate knowledge immune to any dispute of power in establishing itself as such. In this regard Varela, in reflecting on pedagogical knowledge and its articulation that lead to the pedagogization of knowledge, affirms that "pedagogy rationalizes, in general, a certain academic organization and certain forms of transmission without ever questioning the arbitrariness of this organization, nor the usage of knowledge that is the object of transmission" (VARELA, 2002, p.93).

Another matter is the head teacher's methodological practice of using two opposite collections, as much in regards to what is destined for the public as in the very methods proposed. The distance between what is proposed by the National Standard Curriculum and what is actually 
developed in the classroom could be called occult curriculum, but it remains that which characterizes curriculum, a battleground between power and knowledge, a game of truths that produces identities.

\section{Some possibilities for Youth and Adult Education from a post-critical viewpoint:}

From a post-critical viewpoint, the proposal of a Youth and Adult Education would take into account the subject not from the humanist point of view, like she who should be educated for her own emancipation, but a de-centered subject, constructed from the discourse that produces her various identities. The regimes of truth in circulation would also be problematized, which are established by the disciplines included in the curriculum or in other words, said disciplines and their various knowledge would be present without putting them into a hierarchy. In the same way, in horizontal relationships between students and teacher, the relationships of power are present, in "capillary form." This power also brings knowledge and it for this reason that it is positive. The relationships of power occur because they have their positive, productive and transformative side as well.

According to Foucault, "what enables power to maintain itself and be accepted is simply that it does not weigh only as a force that says no, but in reality it permeates, produces things, induces pleasure, forms knowledge and produces speech" (2001, p. 8).

With the end goal of meta-narratives, the knowledge materialized in the curriculum would be more attuned to local and specific questions, considering voices and the narratives of each social, cultural, religious and sexual group that has until now been unappreciated.

Educational reality and especially youth and adult education, facing the paradigmatic shift that is presenting itself, is complex and presents us 
with challenges. We understand that ready-made answers do not exist, as we had until now been accustomed to believing. A critical posture has become necessary when faced with the plurality of views that circulate among us so that we can reflect on our educational practice and decide which course to take.

\section{References}

ANPED (2002) - Educação: manifestos, lutas e utopias. GT: Educação de jovens e adultos. $25^{\text {a }}$ reunião, Caxambu, MG.

CARLOS, Erenildo João (2002). O discurso sobre a EJA: uma possibilidade de análise na perspectiva foucaultiana. In: VASCONCELOS, José Geraldo; MAGALHAES JUNIOR, Antonio Germano. (Orgs.) Um dispositivo chamado Foucault. Fortaleza: LCR, p.79111.

COSTA, Marisa Vorraber (Org) (1998). Educação popular hoje. São Paulo: Loyola.

DEACON, Roger; PARKER, Ben (2002). Educação como sujeição e como recusa. In: SILVA, Tomas Tadeu (Org.). O sujeito da educação: Estudos foucaultianos. 5.ed.. Petrópolis: Vozes. p.97-110.

ESCOLANO, Augustin (2002). Arquitetura como programa. EspaçoEscola e Currículo. In: FRAGO, A V.; ESCOLANO. A. Currículo, espaço e subjetividade. Tradução Alfredo Veiga-Neto. Rio de Janeiro: DP\& A ,p.59-139.

FREIRE, Paulo (2000). Pedagogia da autonomia: saberes necessários à pratica educativa. 15.ed São Paulo: Paz e Terra.

(1993). Pedagogia do oprimido. 17.ed. Rio de Janeiro: Paz e Terra.

FOUCAULT, Michel (1995). O sujeito e o poder. In: RABINOW, Paul e DREYFUS, Hubert. Michel Foucault, uma trajetória filosófica: para além do estruturalismo e da hermenêutica. Tradução Vera Porto Carrero. Rio de Janeiro: Forense Universitária. p. 231-249.

(2001a) Microfísica do poder. 16. ed. Organizador Roberto Machado. Rio de Janeiro: Graal.

(2001b) Vigiar e punir: o nascimento da prisão. 24. ed. Tradução Raquel Ramalhete. Petrópolis: Vozes. 
FRAGO, Antonio Viñao (2001). Do espaço escolar e da escola como lugar: propostas e questões. In: FRAGO, A V.; ESCOLANO. A. Currículo, espaço e subjetividade. Tradução Alfredo Veiga-Neto. Rio de Janeiro: DP\&A, p.59-139.

GOERGEN, Pedro (2001). Pós-modernidade, ética e educação. Campinas: Autores Associados.

GOIÁS. Portaria no 3914 de 28 de maio de 2001. Secretaria Municipal da Educação, Cultura, Esportes e Ecologia - Educação de Jovens e Adultos Currículo Pleno.

GORE, Jennifer M. (2002). Foucault e Educação: fascinantes desafios. In: SILVA, Tomaz Tadeu (Org) O sujeito da educação: Estudos foucaultianos. 5. ed. Petrópolis: Vozes, p.9-20.

LAVILLE, Christian; DIONNE, Jean (1999). A construção do saber: manual de metodologia da pesquisa em ciências humanas. Tradução Heloísa Monteiro e Francisco Settineri. Porto Alegre: Editora Artes Médicas Sul Ltda; Belo Horizonte: Editora UFMG, 1999.

LARROSA, Jorge (2002). Tecnologias do Eu e educação. In: SILVA, Tomaz Tadeu (Org). O sujeito da educação: Estudos foucaultianos. 5. ed. Petrópolis: Vozes, p.35-86.

MARTOS, Cloder Rivas (1995). Viver e aprender: Português 1. 7. ed. São Paulo: Saraiva.

SOARES, Leôncio José Gomes (2001). As políticas de EJA e as necessidades de aprendizagem dos jovens e adultos. In: RIBEIRO, Vera Masagão (org.) Educação de jovens e adultos: Novos leitores, novas leituras. Campinas: Mercado de Letras: Associação de Leitura do BrasilALB; São Paulo: Ação Educativa. (Coleção Leituras no Brasil), p. 201-224.

SILVA, Tomaz Tadeu da (2001). Documentos de identidade: uma introdução às teorias do currículo. 2.ed. Belo Horizonte: Autêntica. (1999). O currículo como fetiche: a poética e a política do texto curricular. Belo Horizonte: Autêntica.

VARELA, Júlia (2002). O estatuto do saber pedagógico. In: SILVA, Tomas T (Org.). Sujeito da educação: estudos foucaultianos. 5.ed. Petrópolis: Vozes, p.87-96

VERISSÍMO, Mara Rúbia Alves Marques (1997 a.). Pós-modernidade e iluminismo: Crítica à Sociologia Modernista. Revista Educação e Filosofia, Uberlândia, v.11, n.21 e 22, p.163-180, jan.jun. e jul.dez. 
(1997 b). Os desafios da pós-modernidade à pedagogia. Ensino em Re-Vista. Uberlândia, v.1, n. 5, p.23-44, jul 1996/ jun.

VIVER, APRENDER (1998). Educação de jovens e adultos (Livro 1) Cláudia Lemos Vóvio (coordenação);[ilustrações de Cecília Esteves]. São Paulo: Ação Educativa; Brasília: MEC.

VÓVIO, Cláudia Lemos (2001). Viver, aprender: uma experiência de produção de materiais didáticos para jovens e adultos. In: RIBEIRO, Vera Masagão (Org.) Educação de jovens e adultos: Novos leitores, novas leituras. Campinas: Mercado de Letras: Associação de Leitura do BrasilALB; São Paulo: Ação Educativa, p.125-136 (Coleção Leituras no Brasil).

\section{Author}

Elizabeth Gottschalg RAIMANN

Work Address: UFG/Campus Jataí, Rua Riachuelo, Setor Samuel Grahan, CEP: 75.800-000 - Jataí/GO

Email: elizabethraimann@gmail.com

Degree: Pedagogy (ILES/Itumbiara-GO),

Specialization: Organizational Pedagogy - emphasis on human development (ULBRA),

Master of Education (Federal University of Uberlândia/MG),

Currently a doctoral student in education (Federal University of Uberlândia/MG)

Institute of Instruction: Federal University of Goiás/ Jataí Campus

Position: Professor of Pedagogy at the Jataí/UFG campus

Elizabeth Gottschalg Raimann, elizabethraimann@gmail.com,

Federal University of Goiás/Jataí Campus

\section{WORK CITED:}

RAIMANN E. G. Curriculum and Youth and Adult Education: Power/Knowledge Space Cultivating Literacy in Portuguese-Speaking Countries. Online-Only Journal. 2.5. (2014): $110 \quad-123$ <http://www.acoalfaplp.net/en_index.html>. 